\title{
Surveillance of women at high risk for hereditary ovarian cancer is inefficient
}

\author{
AL Oei", , LF Massuger', J Bulten ${ }^{2}$, MJ Ligtenberg ${ }^{3}$, N Hoogerbrugge $^{3,4}$ and JA de Hullu' \\ 'Department of Obstetrics and Gynaecology, Radboud University Nijmegen Medical Centre, PO Box 9101, 6500 HB Nijmegen, The Netherlands; \\ ${ }^{2}$ Department of Pathology, Radboud University Nijmegen Medical Centre, PO Box 9101, 6500 HB Nijmegen, The Netherlands; ${ }^{3}$ Department of Human \\ Genetics, Radboud University Nijmegen Medical Centre, PO Box 9101, 6500 HB Nijmegen, The Netherlands; ${ }^{4}$ Department of Medical Oncology, \\ Radboud University Nijmegen Medical Centre, PO Box 9101, 6500 HB Nijmegen, The Netherlands
}

To determine the effectiveness of annual gynaecological screening (pelvic examination, transvaginal ultrasound, and CA-I25), a prospective cohort study of women at high risk for hereditary ovarian cancer was conducted. Women were offered DNA analysis followed by either annual screening or prophylactic bilateral salpingo-oophorectomy (BSO). Study population consisted of 5 I 2 highrisk women (median follow-up 2.07 years, range 0-9.4 years): 265 women (52\%) had a BRCA mutation. Persisting abnormalities indicated diagnostic surgery in 24 women resulting in one primary ovarian cancer FIGO stage IIIc was found. The effectiveness of screening was studied by calculating the probability of finding ovarian cancers in the BRCA-I and BRCA-2 carrier group and comparing this to the identified number of ovarian cancers. The number of ovarian cancer patients found at surveillance was in accordance with the predicted number of ovarian cancers. A total number of 169 women underwent prophylactic BSO: one ovarian cancer stage Ilb was found. In conclusion, the surveillance programme for hereditary ovarian cancer does identify patients with ovarian cancer but is very inefficient considering the high number of surveillance visits and the advanced stage of ovarian cancer in the identified patient. For prevention of advanced stage ovarian cancer, prophylactic BSO from age 35-40 years is a more efficient alternative.

British Journal of Cancer (2006) 94, 8I4-819. doi:I0.1038/sj.bjc.66030I5 www.bjcancer.com

Published online 2I February 2006

(C) 2006 Cancer Research UK

Keywords: BRCA; surveillance; ovarian cancer; prophylactic surgery; hereditary cancer

During the past two decades hereditary cancer has attracted a great deal of interest. Overall, the majority of cancers is sporadic, for example, only $5-10 \%$ of the ovarian cancers are hereditary (Garber and Offit, 2005). In general there is a suspicion of hereditary cancer when more than one primary tumour in the same patient is present, several first or second-degree relatives have cancer and/or cancer developed at an extremely early age.

In 1994 and 1995, mutations in the BRCA-1 and $B R C A-2$ gene were identified as a cause of hereditary breast and ovarian cancer (Scully et al, 1996; King et al, 2003). The lifetime risk of carriers for developing ovarian cancer is high, $35-60 \%$ for BRCA-1 mutation carriers and $10-20 \%$ for $B R C A-2$ mutation carriers, in contrast to the $1.8 \%$ lifetime risk of the general population (Ford et al, 1995; Antoniou et al, 2003). BRCA mutation carriers are also at risk for fallopian tube and primary peritoneal cancer, which usually presents with similar clinical features as ovarian cancer. Moreover, carriers have a $60-85 \%$ lifetime risk of developing breast cancer (Ford et al, 1995; Antoniou et al, 2003). Incidence rates for breast and ovarian cancer in $B R C A$ mutation carriers have been estimated by Antoniou et al (2003).

*Correspondence: Dr AL Oei; E-mail: A.Oei@obgyn.umcn.nl Received 13 December 2005; revised 26 January 2006; accepted 30 January 2006; published online 2I February 2006
$B R C A-1$ and $B R C A-2$ mutation carriers often participate in a surveillance programme for early detection of ovarian cancer consisting of annual pelvic examination and transvaginal ultrasound (TVU) combined with serum CA-125 assessment. As the prognosis of ovarian cancer is poor and the efficacy of this surveillance method has not been proven, prophylactic bilateral oophorectomy seems to be an attractive alternative. Since the discovery of an association between a $B R C A$ mutation and the development of fallopian tube cancer, bilateral oophorectomy has been extended to bilateral salpingo-oophorectomy (BSO) (Zweemer et al, 2000; Olivier et al, 2004). Bilateral salpingo-oophorectomy (BSO) appeared to reduce not only the risk of ovarian cancer by up to $96 \%$, but also the risk of breast cancer in pre-menopausal women by approximately 50\% (Kauff et al, 2002; Rebbeck et al, 2002; Calderon-Margalit and Paltiel, 2004). Furthermore, Madalinska et al (2005) found no difference in quality-of-life between women who underwent prophylactic BSO and women who chose for periodic screening for ovarian cancer although women after prophylactic BSO had fewer concerns about developing breast and ovarian cancer. Whether or not to continue the surveillance after BSO, because of the remaining risk of primary peritoneal cancer, is subject to discussion.

The aim of this study is to evaluate the efficacy of surveillance for hereditary ovarian cancer at the Family Cancer Clinic at the tertiary referral centre of the Radboud University Nijmegen Medical Centre, The Netherlands. 


\section{MATERIALS AND METHODS}

\section{Study population}

A total number of 512 women enrolled in the surveillance programme for hereditary ovarian cancer from January 1995 until January 2005 at the Family Cancer Clinic of the Radboud University Nijmegen Medical Centre, The Netherlands. Between 1995 and 1999 women enrolled in the surveillance programme through self-reference, reference by the department of human genetics, the general practitioner or other specialists. After 1999, women were first counselled at the department of human genetics and referred to the gynaecologist when indicated. Criteria for ovarian surveillance by the gynaecologist are described in Table 1. DNA testing was offered when a $B R C A$ mutation was suspected based on criteria of the department of human genetics.

Primary surveillance was started at the age of 35 or 5 years earlier than the youngest family member with ovarian cancer. When a mutation was found in a hereditary breast and ovarian cancer family during the surveillance programme, all family members who did not carry the mutation were excluded from the surveillance program.

At primary surveillance, information on vital status, age of menarche, use of oral contraceptives, parity, breastfeeding, medical history, occurrence of cancer in the family and pre- or post-menopausal status, was collected. Furthermore, patients were counselled on the possibilities to manage their high-risk status. Their options consisted of annual surveillance or BSO.

\section{Annual surveillance}

Surveillance visits were performed annually and included pelvic examination, transvaginal ultrasound (TVU) and serum CA-125 measurements. Transvaginal ultrasound (TVU) was abnormal in case of the following morphological abnormalities: multiple cysts, cyst with thick septa, papillary projection, irregular patterns or a variety in sonoluency. Cutoff value for CA-125 was $35 \mathrm{U} \mathrm{ml}^{-1}$. In case of an abnormal pelvic examination and/or TVU and/or CA125 , revision after 3 months was advised, unless the findings were highly suspicious for a malignancy in which case diagnostic surgery was performed. Initially, only the abnormal surveillance test was repeated. The other surveillance tests were repeated when the abnormal finding persisted and a diagnostic laparoscopy was considered. When diagnostic laparoscopy was unremarkable or only one ovary and/or tube was removed, the patient returned to the surveillance programme. Occasionally, TVU was performed without routine measurement of CA-125 and/or pelvic examination because the woman had recently visited her own gynaecologist at the referring hospital.

\section{Prophylactic bilateral salpingo-oophorectomy (BSO)}

At primary counselling, patients were informed about the possible advantages (reduction of the risk of ovarian and breast cancer) and disadvantages (surgery, premature menopause, residual risk of

Table I Criteria for referral to the gynaecologist for ovarian surveillance (Vasen et al, 1998; Sutcliffe et al, 2000)

\section{Criteria for referral}

- Women with a proven BRCA-I and/or a BRCA-2 mutation.

- Women from a family with a proven BRCA mutation but who are not (yet) tested for a mutation.

- Women with first- or second-degree relatives with breast cancer before the age of 50 , and ovarian cancer in the family.

- Two first-degree relatives or one first-degree and one second-degree relative with ovarian cancer, independent of age. peritoneal cancer) of a BSO and about the technical aspects (anaesthesia, risk of conversion into laparotomy). Patients who preferred BSO underwent laparoscopy and the ovaries as well as the fallopian tubes were removed. Hysterectomy was not part of the standard operation. All removed ovaries and tubes were separately histopathologically examined: a small piece of each ovary was frozen for further analysis in the future, macroscopic investigation for abnormalities and transverse sectioning of the ovary and fallopian tubes was performed. The tissue sections were formalin-fixed and paraffin-embedded. Standard $4 \mu \mathrm{m}$ thick haematoxylin and eosin-stained sections were used for histopathological examination.

After prophylactic BSO, women underwent follow-up for several years with annual CA-125 measurement. Since 2002 only one follow-up visit was performed and when no abnormalities were found the women were excluded from further control.

To check for the development of peritoneal cancer in any of the women who participated in our study the national pathology database (PALGA), in which all pathological diagnoses in the Netherlands are collected, was consulted for the existence of pathology reports with the diagnosis of ovarian, fallopian tube and peritoneal cancer of each woman until the first of January 2005.

\section{Statistical analysis}

Data analysis was performed using SPSS 12.0.1 software packet (SPSS Inc. Chicago) and Microsoft Excel. The calculated incidence rates were based on incidence rates found by Antoniou et al (2003). Differences between characteristics were tested two-sided with the $\chi^{2}$-test with Yates' correction for small numbers, when necessary. Differences in continuous characteristics, like age, were tested with the $t$-test. $P$-values $\leqslant 0.05$ were considered significant.

\section{RESULTS}

\section{Patient characteristics}

The median age of all 512 women at enroliment in the surveillance programme was 42 years (range $20-75$ years). An overview of the

Table 2 Patient characteristics of 512 women at primary surveillance

\begin{tabular}{lcc}
\hline Study population & & \\
\hline Median age & 42 years & Range 20-75 years \\
Median follow-up & 2.07 years & Range 0-9.4 years \\
Type mutation no. (\%) & Number & Percentage \\
BRCA-I & 180 & $(34.2 \%)$ \\
BRCA-2 & 84 & $(16 \%)$ \\
BRCA-I and BRCA-2 & 1 & $(0.2 \%)$ \\
No mutation ${ }^{\mathrm{a}}$ & 99 & $(19.1 \%)$ \\
Unknown & 6 & $(1.5 \%)$ \\
Not tested & 142 & $(27.3 \%)$ \\
& & \\
Menopausal state & 502 & $(72.7 \%)$ \\
Pre-menopausal & 372 & $(25.4 \%)$ \\
Post-menopausal & 130 & $(1.9 \%)$ \\
Missing & 10 & $(38.8 \%)$ \\
Previous oral contraceptive use & 199 & $(78.7 \%)$ \\
Previous pregnancy & 403 & $(32.1 \%)$ \\
Previous breast cancer & 105 & $(33.4 \%)$ \\
Previous abdominal surgery & & $(1.9 \%)$ \\
Unknown & 171 & \\
\hline
\end{tabular}

These patients underwent DNA testing during the surveillance programme and appeared to have no mutation. ${ }^{b}$ Abdominal surgery: for example, caesarean section(s), abdominal hysterectomy, salpingo-oophorectomy and appendectomy or other abdominal operations. 
patient characteristics is given in Table 2. Ten women died during the surveillance period: seven died of breast cancer metastases, two died of massive lung embolism and in one case the cause of death was unknown. No patients died of ovarian cancer or primary peritoneal cancer.

\section{Ovarian cancer surveillance}

A total of 1621 surveillance visits were performed. The median number of surveillance visits per patient was two (range 1-13 visits) and the median follow-up was 2.07 years (range 0-9.4 years) in a total follow-up of 1029 women-years. See Table 3 for the results of pelvic examination, TVU and CA-125 measurements. In

Table 3 Overview of initially abnormal findings at surveillance and follow-up

\begin{tabular}{lcr}
\hline Surveillance findings & $\begin{array}{c}\text { Number of } \\
\text { abnormal } \\
\text { findings }\end{array}$ & $\begin{array}{c}\text { Number of } \\
\text { abnormalities } \\
\text { that disappeared } \\
\text { after 3-6 months }\end{array}$ \\
\hline Pelvic examination $(n=1372)$ & $\mid 1(2 \%)$ & $5(45 \%)$ \\
CA- I25 $\left(\cup \mathrm{ml}^{-1}\right)(n=\mid 278)$ & $50(4 \%)$ & $43(86 \%)$ \\
Transvaginal ultrasound $(n=\mid 493)$ & $317(2 \mid \%)$ & $295(93 \%)$ \\
Total $(n=4 \mid 43)$ & $378(9 \%)$ & $\mathbf{3 4 3 ( 9 | \% )}$ \\
\hline
\end{tabular}

$91 \%$ in bold emphasizes the percentage. the majority of initial abnormal diagnostic tests $(343 / 378=90.7 \%)$, the abnormality could no longer be observed within 3-6 months.

Diagnostic laparoscopy due to abnormal findings at pelvic examination and/or TVU and/or CA-125 was indicated in 24 women. The median time between first surveillance and the diagnostic laparoscopy was 5 months (range 4-98 months). See Table 4 for an overview of the indications and outcome of these 24 diagnostic laparoscopies. Diagnostic laparoscopy was never indicated solely on a single abnormal pelvic examination (normal TVU and CA-125). The diagnostic laparoscopy procedure was converted to laparotomy in three cases $(12.5 \%)$ owing to the size of the enlarged ovaries. One FIGO stage IIIc ovarian cancer was diagnosed during diagnostic surgery in a 52-year-old carrier of a BRCA-1 mutation with a history of breast cancer.

During the surveillance programme 99 women out of the 364 women who underwent DNA analysis appeared not to carry a $B R C A$ mutation. Thirteen of these women were members of a family in which a mutation was detected, 86 women were member of a family with no mutation but were at increased risk of ovarian cancer based on the family history. In retrospect, the 13 women without a mutation from a proven mutation family were not at high risk of ovarian cancer. These 99 women underwent 425 surveillance visits, seven had a prophylactic BSO and six had a diagnostic laparoscopy.

Incidence rates of the $B R C A-1$ and $B R C A-2$ mutation carriers based on incidence rates found by Antoniou et al (2003) are shown in Table 5. In our group of $B R C A-1$ mutation carriers we calculated a $92 \%$ incidence rate in 248 woman-years. According to these

Table 4 Overview of indications and results of diagnostic laparoscopies in 24 women

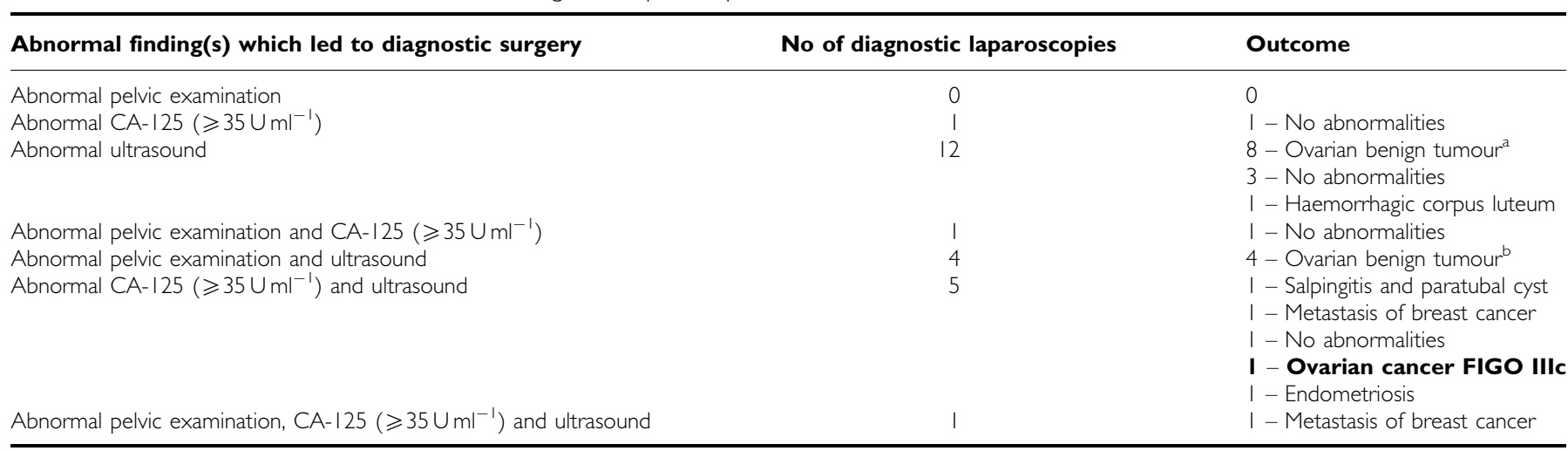

FIGO, International Federation of Gynecology and Obstetrics. aln this group two patients had diagnostic laparoscopy converted to laparotomy. ${ }^{\text {In }}$ this group one patient had diagnostic laparoscopy converted to laparotomy. Ovarian cancer FIGO IIIc in bold emphasizes the finding of only one ovarian cancer.

Table $5 \quad B R C A-I$ mutation carriers incidence during surveillance

\begin{tabular}{|c|c|c|c|c|c|c|c|c|}
\hline Age group (years) & \multicolumn{2}{|c|}{ Follow-up (years) } & \multicolumn{2}{|c|}{ Group incidence (\%) } & \multicolumn{2}{|c|}{ Total group incidence (\%) } & \multicolumn{2}{|c|}{ No surveillance visits } \\
\hline $25-29$ & 38.54 & 2.65 & 0.002 & 0.002 & 0.077 & 0.005 & 69 & 10 \\
\hline $30-34$ & 80.05 & 30.16 & 0.18 & 0.004 & 14.409 & 0.120 & 115 & 43 \\
\hline $35-39$ & 75.61 & 20.06 & 0.28 & 0.01 & 21.170 & 0.200 & 158 & 34 \\
\hline $40-44$ & 25.51 & 6.45 & 0.87 & 0.08 & 22.193 & 0.516 & 53 & 18 \\
\hline $55-59$ & 3.54 & 3.60 & 1.19 & 0.75 & 4.212 & 2.700 & 13 & 12 \\
\hline $60-64$ & 0.80 & 1.53 & 2.26 & 0.38 & 1.808 & 0.581 & 3 & 5 \\
\hline $65-69$ & 2.09 & 0.30 & 2.49 & 0.42 & 5.204 & 0.126 & 4 & । \\
\hline$>70$ & 0.30 & & & 0.001 & & & i & \\
\hline Total & 248.1 & 82.68 & & & 92.095 & 8.667 & 470 & 170 \\
\hline
\end{tabular}

${ }^{a}$ Based on incidence rates of Antoniou et al (2003). 
calculations we predicted to find one ovarian cancer, which was subsequently observed. In 82 woman-years of the $B R C A-2$ mutation carrier group a $8.7 \%$ incidence rate was calculated. In line with these calculations, we did not find an ovarian cancer case in this group.

\section{Prophylactic BSO}

Prophylactic BSO was chosen by 169 women $(169 / 512=33 \%)$. Of these 169 women, $149(88.1 \%)$ were carrier of a genetic mutation: $104 B R C A-1,44 B R C A-2$ and one woman was a carrier of both mutations. Twenty women without a $B R C A$ mutation underwent a prophylactic BSO (seven had no mutation, the results of DNA analyses of five women were pending, seven women were not yet tested and in one woman the DNA status was unknown).

The median time between primary surveillance and BSO was 4 months (range 0-111 months). The median age of the women, who chose prophylactic BSO was 45 years (range 29-70 years). Eleven BSOs were converted to laparotomy due to intra-abdominal adhesions and/or otherwise not being able to resect the ovaries and tubes completely. One $(0.6 \%)$ BSO was complicated by a wound infection. Of all BSOs, one (0.6\%) FIGO stage IIb ovarian cancer was diagnosed in a 60-year-old BRCA-2 mutation carrier with a history of breast cancer. The BSO was performed within one year after primary surveillance.
Final histopathological examination of the other ovaries and tubes showed one borderline malignancy, one dysplasia of the Fallopian tube and 31 cases with benign conditions, for example, serous cysts of the ovaries and endometriosis. All other histopathological examinations of the ovaries and Fallopian tubes were normal. Until the first of January 2005 no primary peritoneal cancers were diagnosed in these women after BSO.

\section{DISCUSSION}

In this large, single-institution analysis, only two cases of ovarian cancer were diagnosed during annual surveillance for several years, among 512 women at high hereditary risk of ovarian cancer. One ovarian cancer (FIGO stage IIIc) was diagnosed at diagnostic laparoscopy after abnormal findings at the first surveillance visit in a 52-year-old patient with a history of breast cancer and carrier of a BRCA-1 mutation. The other ovarian cancer (FIGO stage IIb) was diagnosed after BSO, which was intended to be prophylactic after normal surveillance 4 months earlier, in a 60 -year-old patient with a history of breast cancer and carrier of a BRCA-2 mutation. No interval cancers were identified.

The predicted number of ovarian cancers related to age and the presence of a BRCA mutation was calculated, using the incidence rates of Antoniou et al (2003). Based on these calculations the

Table 6 Overview of literature: surveillance for ovarian cancer in high-risk women

\begin{tabular}{|c|c|c|c|c|c|c|c|c|}
\hline Study & Oei (2006) & $\begin{array}{l}\text { Stirling et al } \\
(2005)\end{array}$ & $\begin{array}{l}\text { Meeuwissen } \\
\text { et al }(2005)\end{array}$ & $\begin{array}{l}\text { Vasen et al } \\
(2005)\end{array}$ & $\begin{array}{l}\text { Laframboise } \\
\text { et al (2002) }\end{array}$ & $\begin{array}{l}\text { Scheuer et al } \\
(2002)\end{array}$ & $\begin{array}{l}\text { Kauff et al } \\
(2002)\end{array}$ & $\begin{array}{l}\text { Dorum et al } \\
\text { (I999) }\end{array}$ \\
\hline $\begin{array}{l}\text { Mean age of } \\
\text { patients in years } \\
\text { (range) }\end{array}$ & $40(20-75)$ & Unknown & $42(18-77)$ & Unknown & $47(22-70)$ & $47.7(24.1-79)$ & $45.5(35-77.7)$ & $4 \mid(18-77)$ \\
\hline No. of patients & $\begin{array}{l}512 \text { high-risk } \\
\text { women }\end{array}$ & $\begin{array}{l}\text { I I I0 high-risk } \\
\text { women }\end{array}$ & $\begin{array}{l}383 \text { high-risk } \\
\text { women }\end{array}$ & $\begin{array}{l}\text { I38 high-risk } \\
\text { women }\end{array}$ & $\begin{array}{l}311 \text { high-risk } \\
\text { women }\end{array}$ & $\begin{array}{l}251 \text { mutation } \\
\text { carriers }\end{array}$ & $\begin{array}{l}170 \text { mutation } \\
\text { carriers }\end{array}$ & $\begin{array}{l}754 \text { high-risk } \\
\text { women }\end{array}$ \\
\hline $\begin{array}{l}\text { No. of patients } \\
\text { with a mutation }\end{array}$ & $\begin{array}{l}\text { I } 80 \text { BRCA- I } \\
84 \text { BRCA-2 } \\
\text { I BRCA-I } \\
\text { and BRCA-2 }\end{array}$ & Unknown & $\begin{array}{l}127 \text { BRCA-1 } \\
25 \text { BRCA-2 }\end{array}$ & $\begin{array}{l}77 \text { BRCA-1 } \\
18 \text { BRCA-2 }\end{array}$ & $\begin{array}{l}26 \text { BRCA-1 } \\
5 \text { BRCA-2 }\end{array}$ & $\begin{array}{l}251 \text { (distribution } \\
\text { unknown) }\end{array}$ & $\begin{array}{l}104 \text { BRCA-1 } \\
66 \text { BRCA-2 }\end{array}$ & Not tested \\
\hline $\begin{array}{l}\text { No. of surveillance } \\
\text { consults }\end{array}$ & $|62|$ & 3701 & 1273 & 227 & 1555 & $\begin{array}{l}\text { Unknown } \\
\text { (89 women) }\end{array}$ & 350 & Unknown \\
\hline $\begin{array}{l}\text { No. of diagnostic } \\
\text { surgeries }\end{array}$ & 24 & 29 & 20 & 36 & 9 & 10 & 11 & Unknown \\
\hline $\begin{array}{l}\text { Incidence of cancer } \\
\text { in women } \\
\text { undergoing } \\
\text { surveillance } \\
\text { (FIGO stage) }\end{array}$ & $\begin{array}{l}\text { I ovarian } \\
\text { | x Stage I|lc }\end{array}$ & $\begin{array}{l}10 \text { ovarian } \\
3 \times \text { Stage Ic } \\
1 \times \text { Stage } \mathrm{Ilb} \\
1 \times \text { Stage } \mathrm{Ilc} \\
1 \times \text { Stage IIIb } \\
3 \times \text { Stage IIIc } \\
\mid \times \text { Stage IV }\end{array}$ & $\begin{array}{l}\mathrm{I} \times \text { breast } \\
\text { metastasis }\end{array}$ & $\begin{array}{l}6 \text { ovarian } \\
5 \times \text { Stage III } \\
\text { I } \times \text { Stage IV }\end{array}$ & $\begin{array}{l}\text { I ovarian } \\
\text { Stage la }\end{array}$ & $\begin{array}{l}4 \text { ovarian } \\
2 \times \text { Stage | } \\
\mid \times \text { Stage I| } \\
\mid \times \text { Unstaged } \\
\mid \text { peritoneal }\end{array}$ & $\begin{array}{l}4 \text { ovarian } \\
\text { I peritoneal }\end{array}$ & $\begin{array}{l}\text { I } 6 \text { ovarian } \\
6 \times \text { Stage I } \\
4 \times \text { Borderline } \\
\text { stage I } \\
\text { Others unknown }\end{array}$ \\
\hline $\begin{array}{l}\text { Incidence of } \\
\text { interval cancers }\end{array}$ & 0 & 2 & 2 & 0 & 0 & 0 & 0 & 0 \\
\hline $\begin{array}{l}\text { No of patients } \\
\text { choosing for } \\
\text { prophylactic BSO }\end{array}$ & 169 & Unknown & 133 & 97 & Not performed & 90 & 98 & Not performed \\
\hline $\begin{array}{l}\text { Incidence of } \\
\text { diagnosed cancers } \\
\text { at prophylactic } \\
\text { BSO }\end{array}$ & $\begin{array}{l}\text { I ovarian } \\
\mid \text { | } \times \text { Stage ||b } \\
2 \text { breast metastasis }\end{array}$ & $\begin{array}{l}\text { | ovarian } \\
\text { | × Stage ||la }\end{array}$ & $\begin{array}{l}\text { I fallopian } \\
\text { tube } \\
\text { Stage la } \\
\text { I breast } \\
\text { metastasis }\end{array}$ & $\begin{array}{l}\text { I ovarian } \\
\text { Stage IIc } \\
2 \text { fallopian } \\
\text { tube } \\
\text { | × Stage | } \\
\text { | } \times \text { Stage || }\end{array}$ & Not applicable & $\begin{array}{l}2 \text { ovarian } \\
2 \times \text { Stage I }\end{array}$ & I peritoneal & Not applicable \\
\hline
\end{tabular}

Note: All stages ordered in FIGO stage, International Federation of Gynecology and Obstetrics. 
probability of finding one ovarian cancer in the BRCA-1 mutation carrier group was $92 \%$ and the probability of finding one ovarian cancer in the BRCA-2 mutation carrier group was $8.7 \%$ (see Tables 5 and 6). Judging on these calculations the probability of finding an ovarian cancer in the non-BRCA carriers is smaller than that for mutation carriers.

Based on the probability calculations and the findings during surveillance, we conclude that the surveillance programme does identify ovarian cancer patients, but is very inefficient for two reasons: (1) although the patient we identified at surveillance had advanced stage disease only the detection of early-stage disease will lead to an improvement of prognosis which is one of the primary goals of screening. (2) The detection of one patient with ovarian cancer requires disproportioned screening efforts in this group of high-risk women.

The cancer rates published by Antoniou et al (2003) are based on measurements obtained from a population that was tested for $B R C A$ mutations regardless of family history. The women in our study were selected based on family history, which may have led to slightly higher incidence rates than the rates of Antoniou et al (2003).

Other ovarian cancer surveillance publications mainly report about patients with one affected family member (breast and/or ovarian cancer) (Bourne et al, 1991; Dorum et al, 1999). Limited data are available regarding women who enrolled in a study strictly on 'high-risk' criteria as shown in Table 1. This complicates comparisons between the different groups. See Table 6 for an overview of the most recent surveillance studies of high-risk women (TVU, CA-125 with (Dorum et al, 1999; Meeuwissen et al, 2005; Vasen et al, 2005) or without pelvic examination (Kauff et al, 2002; Laframboise et al, 2002; Scheuer et al, 2002; Stirling et $a l, 2005)$. Some studies report detection of advanced stage ovarian cancer, while a disappointing low number of patients appeared to have early stage cancer. Remarkably, only two of the studies cited in Table 6 reported interval cancers. Conversely, in other studies patients with a lower risk of ovarian cancer based on the family history were faced with interval ovarian cancers (van Nagell et al, 2000; Tailor et al, 2003). Stirling et al (2005) annually screened 1,110 high-risk women and only found two early stage (stage I) ovarian cancers. All other ovarian cancer patients had advanced stage disease. Meeuwissen et al (2005) calculated the sensitivity and specificity of this surveillance method and report a limited sensitivity with a high number of false-positive findings. Both groups also concluded that screening for ovarian cancer in high-risk women is highly ineffective.

A 'wait-and-see' protocol was followed regarding patients with abnormal findings during surveillance. This approach was supported by the high percentage $(>90 \%)$ of abnormal findings, which normalized within 3-6 months. Pelvic examination did not have an additional role in detecting significant abnormalities in our patients. In all 1372 pelvic examinations, no isolated abnormality at pelvic examination indicated diagnostic laparoscopy. Apparently, pelvic examination does not have a diagnostic role and can be omitted during surveillance.

Most of the abnormalities at surveillance concerned TVU and/or CA-125 measurements. In $21.2 \%$ of all the TVU and 3.9\% of all CA-
125 measurements abnormalities were detected (see Table 3), probably due to the pre-menopausal status of the majority of women in our study. These women have a variety of both physiological (e.g. menstrual cycle) and benign conditions that can give rise to false-positive abnormalities on TVU (e.g. follicle cysts) or CA-125 measurements (e.g. endometriosis). This observation may have contributed to the high incidence of normalizing abnormalities.

In our study $69 \%$ of the carriers underwent BSO. This percentage is slightly higher than found in previous clinical studies, $58-60 \%$ (Kauff et al, 2002). The percentage of women choosing BSO increases with the age of women. Young women prefer to wait with prophylactic BSO until their family is complete. At the end of the study period, $88(51 \%)$ of the 171 women who chose for screening were under the age of 40 .

The observation that only one BSO patient had early-stage ovarian cancer combined with the low incidence of ovarian cancer in women after BSO confirms earlier reports about the effectiveness of prophylactic BSO in preventing advanced stage ovarian cancer. Rebbeck et al (2002) and Schwartz et al (2003) demonstrated that prophylactic bilateral oophorectomy reduces the risk of ovarian cancer with $85-95 \%$. The observation of one case of ovarian cancer in 169 BSOs is lower than that was observed in other studies (Lu et al, 2000; Rebbeck et al, 2002; Scheuer et al, 2002). Until now BSO is the only evidence-based risk-reducing method for women at high risk of ovarian cancer. Moreover, BSO also reduces the risk of breast cancer in pre-menopausal women. Therefore, we would recommend counselling for prophylactic BSO from the age of 35-40 years in BRCA mutation carriers.

Limitations of our study include the non-randomized and observational design. However, randomizing is ethically impossible between surveillance and no surveillance. Moreover, the calculations using the incidence rates of Antoniou et al (2003) were very helpful in analyzing the effectiveness of surveillance. The data from our study are a representation of daily practice and give a true representation of this clinically relevant group. Studies with a larger group of $B R C A$ mutation carriers and longer follow-up need to be performed before more definitive conclusions can be made.

In conclusion, we report one of the largest studies in women with a proven mutation at high risk of hereditary ovarian cancer in a single institutional setting. This surveillance programme identified one patient with advanced stage ovarian cancer. In retrospect, this reflects the predicted incidence rates for high-risk women in this age group. Apparently, this surveillance programme does identify patients with ovarian cancer but is very inefficient considering the high number of surveillance visits and the advanced stage of ovarian cancer in the identified patient. For prevention of ovarian cancer, prophylactic bilateral salpingooophorectomy from age $35-40$ years is a more efficient alternative.

\section{ACKNOWLEDGEMENTS}

We thank Dr B Mook for critical reading of the manuscript.

\section{REFERENCES}

Antoniou A, Pharoah PD, Narod S, Risch HA, Eyfjord JE, Hopper JL, Loman N, Olsson H, Johannsson O, Borg A, Pasini B, Radice P, Manoukian S, Eccles DM, Tang N, Olah E, nton-Culver H, Warner E, Lubinski J, Gronwald J, Gorski B, Tulinius H, Thorlacius S, Eerola H, Nevanlinna H, Syrjakoski K, Kallioniemi OP, Thompson D, Evans C, Peto J, Lalloo F, Evans DG, Easton DF (2003) Average risks of breast and ovarian cancer associated with $B R C A 1$ or BRCA2 mutations detected in case Series unselected for family history: a combined analysis of 22 studies. Am J Hum Genet 72: $1117-1130$
Bourne TH, Whitehead MI, Campbell S, Royston P, Bhan V, Collins WP (1991) Ultrasound screening for familial ovarian cancer. Gynecol Oncol 43: $92-97$

Calderon-Margalit R, Paltiel O (2004) Prevention of breast cancer in women who carry BRCA1 or BRCA2 mutations: a critical review of the literature. Int J Cancer 112: $357-364$

Dorum A, Heimdal K, Lovslett K, Kristensen G, Hansen LJ, Sandvei R, Schiefloe A, Hagen B, Himmelmann A, Jerve F, Shetelig K, Fjaerestad I, Trope C, Moller P (1999) Prospectively detected cancer in familial 
breast/ovarian cancer screening. Acta Obstet Gynecol Scand 78: 906-911

Ford D, Easton DF, Peto J (1995) Estimates of the gene frequency of BRCA1 and its contribution to breast and ovarian cancer incidence. Am J Hum Genet 57: 1457-1462

Garber JE, Offit K (2005) Hereditary cancer predisposition syndromes. J Clin Oncol 23: 276-292

Kauff ND, Satagopan JM, Robson ME, Scheuer L, Hensley M, Hudis CA, Ellis NA, Boyd J, Borgen PI, Barakat RR, Norton L, Castiel M, Nafa K, Offit K (2002) Risk-reducing salpingo-oophorectomy in women with a BRCA1 or BRCA2 mutation. $N$ Engl J Med 346: $1609-1615$

King MC, Marks JH, Mandell JB (2003) Breast and ovarian cancer risks due to inherited mutations in BRCA1 and BRCA2. Science 302: 643-646

Laframboise S, Nedelcu R, Murphy J, Cole DE, Rosen B (2002) Use of CA125 and ultrasound in high-risk women. Int J Gynecol Cancer 12: 86-91

Lu KH, Garber JE, Cramer DW, Welch WR, Niloff J, Schrag D, Berkowitz RS, Muto MG (2000) Occult ovarian tumors in women with BRCA1 or BRCA2 mutations undergoing prophylactic oophorectomy. J Clin Oncol 18: $2728-2732$

Madalinska JB, Hollenstein J, Bleiker E, van BM, Valdimarsdottir HB, Massuger LF, Gaarenstroom KN, Mourits MJ, Verheijen RH, van Dorst EB, van der Putten $H$, van der Velden K, Boonstra H, Aaronson NK (2005) Quality-of-life effects of prophylactic salpingo-oophorectomy vs gynecologic screening among women at increased risk of hereditary ovarian cancer. J Clin Oncol 23: 6890-6898

Meeuwissen PA, Seynaeve C, Brekelmans CT, Meijers-Heijboer HJ, Klijn JG, Burger CW (2005) Outcome of surveillance and prophylactic salpingooophorectomy in asymptomatic women at high risk for ovarian cancer. Gynecol Oncol 97: 476-482

Olivier RI, van Beurden M, Lubsen MA, Rookus MA, Mooij TM, van de Vijver MJ, van't Veer LJ (2004) Clinical outcome of prophylactic oophorectomy in BRCA1/BRCA2 mutation carriers and events during follow-up. Br J Cancer 90: $1492-1497$

Rebbeck TR, Lynch HT, Neuhausen SL, Narod SA, Van't VL, Garber JE, Evans G, Isaacs C, Daly MB, Matloff E, Olopade OI, Weber BL (2002) Prophylactic oophorectomy in carriers of BRCA1 or BRCA2 mutations. $N$ Engl J Med 346: $1616-1622$

Scheuer L, Kauff N, Robson M, Kelly B, Barakat R, Satagopan J, Ellis N, Hensley M, Boyd J, Borgen P, Norton L, Offit K (2002) Outcome of preventive surgery and screening for breast and ovarian cancer in $B R C A$ mutation carriers. J Clin Oncol 20: $1260-1268$

Schwartz MD, Kaufman E, Peshkin BN, Isaacs C, Hughes C, DeMarco T, Finch C, Lerman C (2003) Bilateral prophylactic oophorectomy and ovarian cancer screening following BRCA1/BRCA2 mutation testing. $J$ Clin Oncol 21: 4034-4041

Scully R, Ganesan S, Brown M, De Caprio JA, Cannistra SA, Feunteun J, Schnitt S, Livingston DM (1996) Location of BRCA1 in human breast and ovarian cancer cells. Science 272: 123-126

Stirling D, Evans DG, Pichert G, Shenton A, Kirk EN, Rimmer S, Steel CM, Lawson S, Busby-Earle RM, Walker J, Lalloo FI, Eccles DM, Lucassen AM, Porteous ME (2005) Screening for familial ovarian cancer: failure of current protocols to detect ovarian cancer at an early stage according to the international Federation of gynecology and obstetrics system. J Clin Oncol 23: $5588-5596$

Sutcliffe S, Pharoah PD, Easton DF, Ponder BA (2000) Ovarian and breast cancer risks to women in families with two or more cases of ovarian cancer. Int J Cancer 87: 110-117

Tailor A, Bourne TH, Campbell S, Okokon E, Dew T, Collins WP (2003) Results from an ultrasound-based familial ovarian cancer screening clinic: a 10-year observational study. Ultrasound Obstet Gynecol 21: $378-385$

van Nagell JR, DePriest PD, Reedy MB, Gallion HH, Ueland FR, Pavlik EJ, Kryscio RJ (2000) The efficacy of transvaginal sonographic screening in asymptomatic women at risk for ovarian cancer. Gynecol Oncol 77: $350-356$

Vasen HF, Haites NE, Evans DG, Steel CM, Moller P, Hodgson S, Eccles D, Morrison P, Stoppa LD, Chang-Claude J, Caligo M (1998) Current policies for surveillance and management in women at risk of breast and ovarian cancer: a survey among 16 European family cancer clinics. European Familial Breast Cancer Collaborative Group. Eur J Cancer 34: $1922-1926$

Vasen HF, Tesfay E, Boonstra H, Mourits MJ, Rutgers E, Verheyen R, Oosterwijk J, Beex L (2005) Early detection of breast and ovarian cancer in families with BRCA mutations. Eur J Cancer 41: 549-554

Zweemer RP, van Diest PJ, Verheijen RH, Ryan A, Gille JJ, Sijmons RH, Jacobs IJ, Menko FH, Kenemans P (2000) Molecular evidence linking primary cancer of the fallopian tube to $B R C A 1$ germline mutations. Gynecol Oncol 76: 45-50 